\title{
Disentangling human from natural factors: Taphonomical value of microanatomical features on archaeological wood and charcoal assemblages
}

\section{A R T I C L E I N F O}

\section{Keywords:}

Archaeological wood and charcoal

Taphonomy

Human practices

Natural factors

\begin{abstract}
A B S T R A C T
Archaeobotanical charcoal and wood analyses rely on the observation of different macro- and microanatomical features affecting wood structure to variable extents. These features may result from a wide range of intrinsic and extrinsic factors alluding to different stages of the wood's taphonomical history: initial growth conditions, human selection, transformation/use and discard, post-depositional processes and archaeological sampling strategies. Papers in this volume address taphonomy in this broad sense, through recent methodological work mainly based on experimentation and case studies from a variety of chrono-cultural and geographical contexts. The authors present a number of tools available to wood and charcoal analysts and discuss their archaeological relevance to characterize anthropogenic and/or natural processes. The presented approaches are complementary and well reflect the extent to which wood and charcoal remains provide new insights into past human practices and social dynamics.
\end{abstract}

\section{Introduction}

Since the beginning of systematic charcoal analysis or anthracology, increasing attention has been given to different types of microanatomical features to advance the discipline's theoretical, methodological and interpretative framework (Vernet, 1992, Thiébault, 2002; Badal, 2004; Damblon, 2013; Fiorentino and Magri, 2008; Badal et al., 2012; Ludemann and Nelle, 2017; Théry-Parisot et al., 2010; DotteSarout et al., 2015; Kabukcu, 2018). In the early stages of anthracology, research was focused on sampling and quantification methods and potential representativeness biases such as fragmentation and mass reduction, which led to establishing the methodological basis of the discipline (Chabal, 1982, 1988, 1992, Chabal, 1994, 1997; Chabal et al., 1999; Krauss-Marguet, 1981; Badal García and Heinz, 1991; Badal, 1992; Pernaud, 1997). The development of an accurate method for charcoal analysis allowed to compare data between sites and to establish reliable paleoecological records (Asouti and Austin, 2005). Beyond these aspects, analyses of microanatomical features on charcoal advanced in two main directions. First, the study of anatomical features to reconstruct firewood management, especially in Paleolithic and Mesolithic contexts for which a systemic interpretative framework was needed (Théry-Parisot, 2001; Henry and Théry-Parisot 2014a; VidalMatutano et al., 2017). Secondly, the study of anatomical features to identify aspects related to woodland management and paleoecological reconstructions (Terral and Mengüal 1999; Marguerie and Hunot, 2007; Ludemann and Nelle 2002; Dufraisse and García-Martinez, 2011; Dufraisse et al., 2018).

Macro- and microanatomical features visible within the ligneous cellular structure depend on different intrinsic and extrinsic factors alluding to various stages of the wood's taphonomical history: initial growth conditions, human selection, transformation/use and discard, post-depositional processes and archaeological sampling strategies.
Initial growth conditions can be reflected by distinguishable anatomical variations of the wood structure resulting from intrinsic or extrinsic natural factors or human activities such as deforestation, pruning or domestication/irrigation (Schweingruber, 2007; Dufraisse, 2006; Terral, 2000; Limier et al., 2018). The identification of the features related to these processes sheds light on woodland management practices and environmental effects on woody plants. Human selection is a major topic in anthracology where the study of anatomical features allows going beyond the taxonomic identification to analyze charcoal assemblages, as aspects related to socio-economical behavior can be approached through studies aiming at reconstructing minimal diameters and state of the wood (green, seasoned, decayed) used. Indeed, the latter are additional indicators of firewood acquisition modalities (woodcutting vs. gathering) and have different implications in terms of heat requirements and fire use (Moskal-del Hoyo et al., 2010; ThéryParisot and Henry, 2012; Henry and Théry-Parisot, 2014b; Mallol and Henry, 2017; Vidal-Matutano et al., 2017). Transformation/use and discard involve different processes subjected to variable archaeological visibility according to the studied material; macro- and microtraces on worked wood allow reconstructing manufacture processes and uses, whereas in the case of charcoal assemblages the combustion constitutes an additional taphonomy filter. Burning induces wood fragmentation and mass reduction, alters the cell walls and can produce specific microanatomical alterations such as cracks and vitrification, in relation to the initial fuel characteristics (Chabal et al., 1999; Théry-Parisot et al., 2010; Théry-Parisot and Henry 2012; McParland et al., 2010). Postdepositional processes and preservation of charcoal or wood in archaeological or natural contexts are diverse. In the course of their depositional or post-depositional history, charcoal particles can be fragmented or hyper fragmented. Anthracological remains are affected by processes indicating the action of mechanical, biological or climatic factors (Chrzazvez et al., 2014). In the case of wood, its preservation 
generally implies specific depositional and post-depositional conditions. Finally, archaeological sampling strategies and recovery methods can have a significant impact on assemblage fragmentation and, more generally, representativeness, which stresses the importance of the traceability of excavation and laboratory methods (Vidal-Matutano, 2017; Arranz-Otaegui, 2017).

To understand processes and classify different features several methods have been applied relying overall on experimentation and ethnoarchaeology (Ntinou, 2002; Théry-Parisot et al., 2009; Henry et al., 2018; Théry-Parisot et al., 2016; Picornell Gelabert et al., 2011; Dussol et al., 2017; Caruso-Fermé et al., 2015; McParland et al. 2010; Dufraisse et al., 2018). Accurate observations of the materials and efforts in understanding the processes involved in the formation of microanatomical features have provided interpretation keys of anthracological materials that are currently at different stages of development.

For the Paleolithic and, more generally, temporary hunter-gatherer occupations, specific questionings related to taphonomy issues and wood-related human behavior in terms of fire management systems are widely being developed. These questionings concern mainly fuel selection and acquisition modalities from an environmental, territorial and functional perspective (Théry-Parisot, 2001; 2002; Théry-Parisot et al., 2010, 2018; Allué 2002, Allué et al., 2009; Henry and ThéryParisot, 2014a; Vidal-Matutano, 2017; Vidal-Matutano et al., 2015, 2019; Alcolea-Gracia, 2018; Allué \& Mas, this volume; Martínez-Varea et al., this volume). These specific chrono-cultural contexts have also led researchers to investigate more in depth the impact of depositional and post-depositional processes in order to contribute to reconstructing on-site taphonomic conditions (Théry-Parisot, 2001; Carrión-Marco and Badal, 2004; Chrzazvez et al., 2014; Marquer et al., 2015; VidalMatutano et al., 2017; Vidal-Matutano, 2017). With increasing anthropogenic pressure from the Neolithic onwards and within more recent, generally better preserved contexts, the development of dendroanthracological tools and multi-proxy approaches have allowed significant advances in the knowledge of past woodland management and agricultural systems (Ludemann and Nelle, 2002; Carrión-Marco, 2005; Delhon et al., 2009, Dufraisse 2006; Terral and Durand, 2006; Delhon et al., 2008; Paradis-Grenouillet and Dufraisse, 2018; Marguerie et al., 2010; Dufraisse and García-Martinez, 2011; Dufraisse et al., 2018; Out et al., 2013). Finally, exceptional contexts such as waterlogged sites where non-charred ligneous materials are preserved allow the adoption of a wider perspective regarding wood uses, from technofunctional and cultural approaches of ligneous materials and artefacts to the reconstruction of woodland management and economies (Carrión-Marco and Rosser, 2010; Chabal and Feugère, 2005; LópezBultó and Piqué, 2018; Zhilin et al., 2018; Klooß, 2014; Martín-Seijo and Carrión, 2012; Mertens, 1998).

\section{Case studies presented in this special issue}

The case studies presented in this volume cover a wide geographic range from Eurasia to South America. The archaeological contexts are also diverse, with a chronological span from the Middle Palaeolithic to historical periods. There is a broad application of new approaches to traditional anthracology that definitely contribute to a better understanding of anatomical features and, more generally, of the anthracological record. These approaches are intended to solve particular issues regarding specific human activities related to wood uses and to understand natural and anthropogenic processes affecting anthracological assemblages.

As previously mentioned, the Paleolithic has traditionally been the most studied period from a taphonomical perspective, probably because many processes related to charcoal aging and decay make evident the need for a deep taphonomic analysis. In this special issue, two papers focus on this period from different perspectives. Martínez Varea et al. (2020) present two case studies, Abrigo de la Quebrada and Cova de les Cendres (Spain) to analyze the taphonomical characteristics of charcoal remains affected by post-depositional processes. The authors analyze preservation conditions involving different type of contexts and human occupation patterns. Allué and Mas (2020) present an overview of microanatomical features observed on Pinus sylvestris type charcoal from Paleolithic sequences in Iberia. As the values provided by the microanatomical features are difficult to interpret in terms of human behavior, they are used as a comparative proxy between archaeological sequences. However, the advance in the description of these features and an accurate classification will allow in the future a better understanding of the meaning of these results with broader implications for wood uses during the Paleolithic.

Charcoal quantification and floristic representativeness of the anthracological spectra (floristic diversity and proportions between taxa) is an important issue in anthracology. The main variables identified as affecting the reliability of charcoal assemblages are the recovery methods used during the excavation, the number of analyzed fragments, the study of different contexts and the origin of the samples (dispersed vs concentrated charcoal assemblages) (Chabal, 1988; 1992; 1997; Chabal et al., 1999; Badal, 1992). The general validity of these premises, mainly built around protohistorical to historical case studies, is reexamined by Henry et al. (2020) for a Mesolithic cave occupation. The objective was to understand the respective contributions of different size classes $(2-4 \mathrm{~mm}$ and $>4 \mathrm{~mm}$ ) and sampling contexts (dispersed vs. concentrated charcoal) on the floristic results of Escabasses Cave (France). The fact that the floristic results vary more according to size class than to sampling context goes against previous observations and invites taking fragment size more systematically into account. Furthermore, this specific situation may have paleothnographic implications regarding the way in which small mobile Mesolithic groups managed fireplaces in a confined space.

Combustion processes entailing wood carbonization have major implications in different aspects affecting archaeological charcoal assemblages. Some work has already been done using experimental archaeology to understand specific processes such as mass reduction, wood anatomy changes and fragmentation (Slocum et al., 1978; Chrzazvez et al., 2014; Gonçalves et al., 2012; Théry-Parisot et al., 2010). Among the alterations resulting from combustion, vitrification is one of the most recurrent, even though it rarely affects the entire assemblage. This glassy and refractive aspect of the wood anatomical cell structure has no accurate explanation yet, even though most of the studies agree that this alteration results from - but cannot be only explained by - the combustion process. Different parameters have been tested and analyzed by several researchers, such as type of combustion process, temperature or initial state of the wood (Théry-Parisot, 2001; McParland et al., 2010; Henry, 2011). Courty (2017) proposed that this alteration results from wood flash-pyrolysis induced by aeroplasma. In this special issue, Courty et al. (2020) present research focused on vitrification affecting different kinds of charcoal remains. The authors present new evidence based on modern burning assemblages and their identification and a detailed process inducing vitrified charcoal. One of the strengths of the study is to provide insights on fuel qualities and pyrotechnology, showing that there are different degrees, and probably different processes, leading to the production of vitrified charcoal components. Vidal-Matutano et al. (2019) present a multi-approach study based on the spatial analysis of charcoal and burned faunal remains to understand the causes of vitrification in an anthracological assemblage from the pre-Hispanic site of Chasogo (Tenerife, Spain). In this study, abundant vitrified wood charcoal fragments seem to be spatially related to the combustion structures and the burnt bones suggesting the relationship of this phenomenon with specific combustion conditions, allowing the discussion of some working hypotheses for future analyses.

Wood management has become an important issue based overall in dendroanthracology, with diameter estimates used for drawing paleoeconomical but also paleoenvironmental hypotheses regarding woodland structure (Carrión, 2005; García-Martínez and Dufraisse, 
2011). Dufraisse et al. (2020) present new methodological developments for the analysis of wood diameter estimation using the Pith Location Tool (PLT). This method, based on trigonometry, was applied to seven different taxa, constituting an important reference dataset. The strengths of this research are to provide measurement protocols and guidelines for an accurate dendroanthracological analysis, as well as an R-function for wood and charcoal fragments allowing a wide use of this tool among the research community.

Caruso-Ferme and Thery-Parisot (2020) apply for the first time an evaluation of the minimal wood caliber to a Patagonian hunter-gatherer site, Cerro Casa de Piedra 7 (Argentina). They propose a comparison between diameters measured on charcoal vs. wood fragments of Nothofagus, the most abundant taxon in this archaeological context. The results show completely different patterns between firewood and wood diameters used at the site throughout time, which has interesting implications regarding wood acquisition strategies of these Patagonian societies.

López-Bultó (2020) presents the famous Neolithic waterlogged wood assemblage of La Draga (Spain), from which he analyses woodworking debris and formless pieces of wood. Indeed, in sites with exceptional preservational conditions, this last category is often left aside in xylological studies. This study confirms the necessity to take them into account, as they allow the discussion of key aspects of wood economies such as raw material selection, transport and manufacturing processes (e.g., Caruso Fermé 2012; Taylor et al. 2018).

Finally, post-depositional processes can be studied from a wide perspective including pedoanthracology as an approach to understand soil formation processes in natural contexts (Scott and Damblon, 2010). Ponomarenko et al. (2020) present a multidisciplinary study based on sedimentology, palynology and pedoanthracology. The study is focused on the discrimination of natural versus anthropogenic causes of erosion phases during historical times in the Middle Volga region. According to the data, different land uses and cultivation techniques are clearly recognizable in the sedimentary profiles of the investigated area. The authors conclude that human practices related to livestock and deforestation are the main cause of erosion.

\section{Concluding thoughts}

Anthracology is a relatively young research field that is still expanding thanks to new analytical methods based on experimental work and actualistic reference datasets in general. Ongoing approaches range from the macroscopic to the molecular levels, with a whole new world of possibilities opening up for a better understanding of both natural and anthropogenic processes. The articles in this SI only represent partially what is going on out there, but in our opinion, they well reflect the fact that charcoal and wood analyses tend to diversify around multiple topics. As shown in this volume, these topics go from paleoenvironmental reconstructions and land-use patterns to very specific questions regarding firewood and wood management, while methodological developments and questionings are still at the heart of the discipline. Much is still left to do to be able to characterize, understand and interpret the many signatures identifiable within the charcoal record, and their relevance for the study of different taxa, archaeological levels, sites and periods. Taphonomic issues are often treated laterally in papers focused on other topics, which often makes it difficult to follow the progress made. In this sense, this volume aims to be a meeting point for the definition, evaluation of archaeological relevance and general discussion of microanatomical signatures observed in archaeological charcoal and wood.

\section{Acknowledgements}

We would like to thank the European Association of Archaeologists for agreeing to host the session 110 "Disentangling human from natural factors: taphonomical value of microanatomical features on archaeological wood and charcoal assemblages" at the EAA Annual Meeting 2018 in Barcelona. Many thanks to the presenters of the 12 oral communications and the poster, as well as to the colleagues who attended the session. Thanks to A. Aşınmaz for his volunteer work as a technician in our session room.

Special thanks to the research projects and institutions that have financially supported the organization of the session:

GDR 3544 "Sciences du bois" and CEPAM-CNRS UMR 7264 laboratory (A. Henry and P. Vidal-Matutano);

research project MINECO Ramón y Cajal program RYC-2014-16027 (Y. Carrión Marco);

research projects MICINN-FEDER PGC2018-093925-B-C32, MINECO (HAR2016-76760-C3-1-P) and the Generalitat de Catalunya research project 2017 SGR 836 (E. Allué).

Many thanks to JAS: Reports for agreeing to host this Special Issue about charcoal taphonomy, especially to Chris O. Hunt, Vinaya Sundar and Ilaria Meliconi.

We also would like to express our deepest gratitude to our colleagues and peers, the 17 reviewers who put a lot of effort in providing useful and pertinent comments, which contributed to improve all of the papers composing this volume. It is important to acknowledge their work, as they agree to perform these evaluation tasks without compensation of any kind, often within an already overloaded work schedule. Thank you for your support, as this Special Issue would not have been possible without your hard work: Cláudia Costa (ICArEHB-FCHS, University of Algarve, Portugal), Claire Delhon (Université Côte d'Azur, CNRS, CEPAM UMR 7264, France), Thomas Feiss (SILVA laboratory, UMR 1434, University of Lorraine, France), Tryfon Giagkoulis (Aristotle University of Thessaloniki, Greece), Lourdes López-Merino (EcoPast Research Group, University of Santiago de Compostela, Spain), Olga Lozovskaya (Institute for the History of Material Culture, Russian Academy of Sciences, Russia), Maria Martín-Seijo (GEPN-AAT, University of Santiago de Compostela, Spain), Jacob Morales (University of Las Palmas de Gran Canaria, Spain), Magdalena Moskal del Hoyo (W. Szafer Institute of Botany, Polish Academy of Sciences, Poland), Maria Ntinou (Aristotle University of Thessaloniki, Greece), Sandrine Paradis (EVEHA, Geolab, Université de Limoges. UMR 6042 CNRS, France), Llorenç Picornell-Gelabert (University of the Balearic Islands, Spain), Philippe Poirier (INRAP, ISEM UMR 5554, France), Vanessa Py-Saragaglia (CNRS, GEODE UMR 5602, France) and three anonymous reviewers.

The remaining errors are, of course, imputable to the authors alone.

\section{References}

Alcolea-Gracia, M., 2018. Donde hubo fuego: estudio de la gestión humana de la madera como recurso en el valle del Ebro entre el Tardiglaciar y el Holoceno Medio. Monografías Arqueológicas 53, Prensas de la. Universidad de Zaragoza.

Allué, E., Mas, B., 2020. The meaning of charcoal taphonomical markers of Pinus sylvestris type in Palaeolithic sites at NE of Iberia. J. Archaeol. Sci.: Rep. 30. https://doi. org/10.1016/j.jasrep.2020.102231.

Allué, E., 2002. Preliminary issues regarding the taphonomic study of archaeological charcoal upon the record from Abric Romani (Capellades, España). In: Renzi, M. (Ed. ), Current topics on taphonomy and fossilization, Ayuntamiento de Valencia, pp. $447-452$.

Allué, E., Euba, I., Solé, A., 2009. Charcoal taphonomy: the study of the cell structure and surface deformations of Pinus sylvestris type for the understanding of formation processes of archaeological charcoal assemblages. J. Taphon. 7 (2-3), 57-72.

Arranz-Otaegui, A., 2017. Evaluating the impact of water flotation and the state of the wood in archaeological wood charcoal remains: implications for the reconstruction of past vegetation and identification of firewood gathering strategies at Tell Qarassa North (south Syria). Quaternary Int. 457, 60-73.

Asouti, E., Austin, P., 2005. Reconstructing woodland vegetation and its exploitation by past societies, based on the analysis and interpretation of archaeological wood charcoal macroremains. Environ. Archaeol. 10, 1-18.

Badal, E., 1992. L'anthracologie préhistorique: à propos de certains problèmes méthodologiques. Bulletin de la Société Botanique de France. Actualités Botaniques 139 (2-4), 167-189.

Badal, E., 2004. Análisis antracológico de los restos del fuego doméstico del abrigo de los Baños (Ariño, Teruel). In: Utrilla, P., Rodanés J.M. (Eds.), Un asentamiento epipaleolítico en el valle del Río Martín. El Abrigo de los Baños (Ariño, Teruel). Monografías Arqueológicas 39, Prensas de la Universidad de Zaragoza, pp. 63-74. 
Badal García, E., Heinz, C., 1991. Méthodes utilisées pour l'étude de sites préhistoriques. In: Waldren, W.H., Ensenyat J.A., Kennard R.C. (Eds.), Ind Deya International Conference of Prehistory : vol. 1. Bar International Series 573, Oxford Archaeopress, pp. 17-47.

Badal, E., Carrión, Y., Macías, M., Ntinou, M. (Eds.) 2012. Wood and charcoal. Evidence for human and natural history. Sagvntvm Extra-13.

Carrión-Marco, Y., 2005. Dendrología y arqueología: las huellas del clima y de la explotación humana de la madera. In: Moiera i Marimon J., Farjas i Silva J., Roura i Grabulosa P., Pradell i Cara T. (Eds.), Avances en Arqueometría 2005. Universitat de Girona, pp. 273-282.

Caruso Fermé, L., 2012. Modalidades y uso del material leñoso entre grupos cazadoresrecolectores patagónicos (Argentina). Métodos y técnicas de estudio del material leñoso arqueológico. Unpubl. Ph. D. thesis, Departament de Prehistòria, Universitat Autònoma de Barcelona.

Carrión-Marco, Y., Badal, E., 2004. La presencia de hongos e insectos xilófagos en el carbón arqueológico. Propuestas de interpretación. In: Martín Calleja, J., Feliu Ortega, M.J., Edreira Sánchez, M. del C. (Eds.), Avances en Arqueometría. Servicio de Publicaciones de la Universidad de Cádiz and Ayuntamiento del Puerto de Santa María, Cádiz, pp. 98-106.

Carrión-Marco, Y., Rosser, P., 2010. Revealing Iberian woodcraft: conserved wooden artefacts from south-east Spain. Antiquity 84 (325), 747-764.

Caruso-Fermé, L.C., Avilés, E.I., Borrero, L.A., 2015. Tracing Driftwood in Archaeological Contexts: Experimental Data and Anthracological Studies at the Orejas De Burro 1 Site (Patagonia, Argentina). Archaeometry 57, 175-193.

Caruso-Fermé, L., Théry-Parisot, I., 2020,. Fuel management in Patagonian hunter-gatherers groups: approach for evaluating the diameter of carbonised wood and noncarbonised wood from Cerro Casa de Piedra 7 site (Argentina). J. Archaeol. Sci.: Rep.

Chabal, L., 1982. Méthodes de prélèvement des bois carbonisés protohistoriques pour l'étude des relations homme-végétation. D.E.A. Université de Montpellier II.

Chabal, L., 1988. L'étude paléoécologique de sites protohistoriques à partir des charbons de bois: la question de l'unité de mesure. Dénombrements de fragments ou pesées? Pact 22 (IV.1), 209-217.

Chabal, L., 1992. La représentativité paléo-écologique des charbons de bois archéologiques issus du bois de feu. In : Vernet, J.-L. (Ed.), Les charbons de bois, les anciens écosystèmes et le rôle de l'homme. Bulletin de la Société Botanique de France. Actualités Botaniques 139 (2-4), Société Botanique de France, Paris, pp. 213-236.

Chabal, L., 1994. Apports récents de l'anthracologie à la connaissance des paysages passés: performances et limites. Histoire \& Mesure 9 (3), 317-338.

Chabal, L., 1997. Forêts et sociétés en Languedoc (Néolithique final, Antiquité tardive): l'anthracologie, méthode et paléoécologie. Documents d'Archéologie Méridionale 63, Editions de la Maison des Sciences de l'Homme, Paris.

Chabal, L., Fabre, L., Terral, J.-F., Théry-Parisot, I., 1999. L'Anthracologie. In: Ferdière, A. (Ed.), La botanique. Errance, Paris, pp. 43-104.

Chabal, L., Feugère, M., 2005. Le mobilier organique des puits antiques et autres contextes humides de Lattara. Lattara 18, 137-188.

Chrzazvez, J., Théry-Parisot, I., Fiorucci, G., Terral, J.-F., Thibaut, B., 2014. Impact of post-depositional processes on charcoal fragmentation and archaeobotanical implications: experimental approach combining charcoal analysis and biomechanics. J. Archaeol. Sci. 44, 30-42.

Courty, M.A., Allué, E., Henry, A., 2020. Forming mechanisms, cultural relevance and environmental implications of vitrified charcoal. J. Archaeol. Sci.: Rep. 30. https:// doi.org/10.1016/j.jasrep.2020.102215.

Courty, M.A., 2017. Fuel origin and firing product preservation in archaeological occupation contexts. Quaternary Int. 431, 116-130.

Damblon, F. (Ed.) 2013. Proceedings of the Fourth International Meefing of Anthracology: Brussels, 8, 13th September 2008, Royal Belgian Institute of Natural Sciences. BAR International Series 2486, Oxford Archaeo Press.

Delhon, C., Martin, L., Argant, J., Thiébault, S., 2008. Shepherds and plants in the Alps: multi-proxy archaeobotanical analysis of Neolithic dung from "La Grande Rivoire" (Isère, France). J. Archaeol. Sci. 35 (11), 2937-2952.

Delhon, C., Thiébault, S., Berger, J.-F., 2009. Environment and landscape management during the Middle Neolithic in Southern France: evidence for agro-sylvo-pastoral systems in the Middle Rhone Valley. Quaternary Int. 200 (1-2), 50-65.

Dotte-Sarout, E., Carah, X., Byrne, C., 2015. Not just carbon: assessment and prospects for the application of anthracology in Oceania. Archaeol. Ocean. 50 (1), 1-22.

Dufraisse, A., 2006. Charcoal anatomy potential, wood diameter and radial growth. In: Dufraisse, A. (Ed.), Charcoal analysis: new analytical tools and methods for archaeology. Papers from the Table- Ronde held in Basel 2004, BAR International Series S1483, Oxford Archaeopress, pp. 47-60.

Dufraisse, A., García-Martinez, M.S., 2011. Mesurer les diamètres du bois de feu en anthracologie. Outils dendrométriques et interprétation des données. Anthropobotanica 2, 1-18.

Dufraisse, A., Bardin, J., Picornell-Gelabert, Ll, Coubray, S., García-Martinez, M.-S., Lemoine, M., Vila Moreiras, S., 2020. Pith location tool and wood diameter estimation: validity and limits tested on seven taxa to approach the length of the missing radius on archaeological wood and charcoal fragments. J. Archaeol. Sci.: Rep. 29. https://doi.org/10.1016/j.jasrep.2019.102166.

Dufraisse, A., Coubray, S., Girardclos, O., Nocus, N., Lemoine, M., Dupouey, J.L., Marguerie, D., 2018. Anthraco-typology as a key approach to past firewood exploitation and woodland management reconstructions. Dendrological reference dataset modelling with dendro-anthracological tools. Quaternary Int. 463, 232-249.

Dussol, L., Elliott, M., Théry-Parisot, I., 2017. Experimental anthracology: evaluating the role of combustion processes in the representivity of archaeological charcoal records in tropical forests, a case study from the Maya Lowlands. J. Archaeol. Sci.: Rep. 12, 480-490.
Fiorentino, G., Magri, D., (Eds.) 2008. Charcoals from the past: Cultural and palaeoenvironmental implications. Proceedings of the Third International Meeting of Anthracology, Cavallino - Lecce (Italy), June 28th - July 1st 2004. BAR Int. Series 1807, Oxford Archaeopress.

García-Martínez, M.-S., Dufraisse, A., 2011. Bronze Age Firewood explotation in south eastern Iberia: a study focusing on wood diameter estimation. Saguntum Extra 11, 187-188.

Gonçalves, T.A., Marcati, C.R., Scheel-Ybert, R., 2012. The effect of carbonization on wood structure of Dalbergia violacea, Stryphnodendron polyphyllum, Tapirira guianensis, Vochysia tucanorum, and Pouteria torta from the Brazilian cerrado. IAWA J. 33 (1), 73-90.

Henry, A., 2011. Paléoenvironnements et gestion du bois de feu au Mésolithique dans le sud-ouest de la France : anthracologie, ethnoarchéologie et expérimentation. Unpubl. $\mathrm{Ph}$. D. Thesis, Université de Nice-Sophia Antipolis.

Henry, A., Théry-Parisot, I., 2014a. Fuel Use and Management during the Mesolithic: Recent Approaches in Archaeobotany, in: Henry A., Marquebielle B., Chesnaux L., Michel S. (Eds.), Techniques and Territories: New Insights into Mesolithic Cultures, Proceedings of the Round table, November 22-23 2012, Maison de la Recherche, Toulouse (France), P@lethnology 6, 65-83.

Henry, A., Coli, V.L., Valdeyron, N., Théry-Parisot, I., 2020. Old taphonomy issues, new charcoal data for Mesolithic contexts: impact of fragment size and sampling context on the assemblages of Escabasses cave (SW France). J. Archaeol. Sci.: Rep. 30. https://doi.org/10.1016/j.jasrep.2020.102232.

Henry, A., Théry-Parisot, I., 2014. From Evenk campfires to prehistoric hearths: charcoal analysis as a tool for identifying the use of rotten wood as fuel. J. Archaeol. Sci. 52, 321-336.

Henry, A., Zavadskaya, E., Alix, C., Kurovskaya, E., Beyries, S., 2018. Ethnoarchaeology of fuel use in northern forests: towards a better characterization of prehistoric firerelated activities. Ethnoarchaeol. 10 (2), 99-120.

Kabukcu, C., 2018. Wood Charcoal Analysis in Archaeology. In: Pişkin, E., Marciniak, A., Bartkowiak, M. (Eds.), Environ. Archaeol. Interdisciplinary Contributions to Archaeology. Springer, pp. 133-154.

Klooß, S., 2014. They were fishing in the sea and coppicing the forest. Terminal Mesolithic and Early Neolithic wooden artefacts of coastal settlements on the southwestern Baltic Sea. In: Harff, J., Lüth, F., SINCOS II- Sinking Coasts: Geosphere, Ecosphere and Anthroposphere of the Holocene Southern Baltic Sea. Bericht der Römisch-Germanischen Kommission 92, 2011 (2014), pp. 251-274.

Krauss-Marguet, I., 1981. Analyse anthracologique du gisement Postglaciaire de la Poujade (Commune de Millau, Aveyron). Paléobiologie Continentale XII 1, 93-110.

López-Bultó, O., 2020. Woodanalysis and beyond: contribution of two times neglected wooden materials to the obtaining and elaboration processes at La Draga (Banyoles, Spain). J. Archaeol. Sci.: Rep. 29. https://doi.org/10.1016/j.jasrep.2019.102122.

López-Bultó, O., Piqué, R., 2018. Wood procurement at the early Neolithic site of La Draga (Banyoles, Barcelona). J. Wetl. Archaeol. 18 (1), 56-76.

Limier, B., Ivorra, S., Bouby, L., Figueiral, I., Chabal, L., Cabanis, M., Ater, M., Lacombe, T., Ros, J., Brémond, L., Terral, J.F., 2018. Documenting the history of the grapevine and viticulture: A quantitative eco-anatomical perspective applied to modern and archaeological charcoal. J. Archaeolog. Sci. 100, 45-61.

Ludemann, T., Nelle, O., 2002. Die Wälder am Schauinsland und ihre Nutzung durch Bergbau und Köhlerei. Schriftenreihe Freiburger forstliche Forschung Band 15, Freiburg im Breisgau.

Ludemann, T., Nelle, O., 2017. Anthracology: local to global significance of charcoal science. Quaternary Int. 457, 1-5.

Mallol, C., Henry, A., 2017. Ethnoarchaeology of Paleolithic fire: methodological considerations. Curr. Anthropol. 58 (S16), S217-S229.

Marguerie, D., Hunot, J.Y., 2007. Charcoal analysis and dendrology: data from archaeological sites in north-western France. J. Archaeol. Sci. 34 (9), 1417-1433.

Marguerie, D., Bernard, V., Bégin, Y., Terral, J.-F., 2010. Dendroanthracologie. In: Payette, S., Filion, L. (Eds.), La dendroécologie. Principes, méthodes et applications. Presses de l'Université Laval, Québec, pp. 311-350.

Marquer, L., Lebreton, V., Otto, T., Messager, E., 2015. Étude des macro-, méso- et microcharbons du site épigravettien de Mezhyrich (Ukraine): données taphonomiques et anthracologiques. L'Anthropologie 119 (4), 487-504.

Martínez Varea, C.M., Carrión, Y., Badal, E., 2020. Preservation and decay of plant remains in two Palaeolithic sites: Abrigo de la Quebrada and Cova de les Cendres (Eastern Spain). What information can be derived? J. Archaeol. Sci.: Rep. 29 (this volume). https://doi.org/10.1016/j.jasrep.2019.102175.

Martín-Seijo, M., Carrión, Y., 2012. Shaping wood: woodworking during the Iron Age and Roman period in the northwest of the Iberian Peninsula. Sagvntvm: Papeles del Laboratorio de Arqueología de Valencia 13, 135-144.

McParland, L.C., Collinson, M.E., Scott, A.C., Campbell, G., Veal, R., 2010. Is vitrification in charcoal a result of high temperature burning of wood? J. Archaeol. Sci. 37 (10), 2679-2687.

Mertens, E.-M., 1998. Hölzerne Fischfanggeräte und ihre Bedeutung für die Ökonomie des Mesolithikums. In: Conard, N.J., Kind, C.-J. (Eds.), Aktuelle Forschungen zum Mesolithikum : Current Mesolithic research. Urgeschichtliche Materialhefte 12, 43-56.

Moskal-del Hoyo, M., Wachowiak, M., Blanchette, R.A., 2010. Preservation of fungi in archaeological charcoal. J. Archaeol. Sci. 37 (9), 2106-2116.

Ntinou, M., 2002. Vegetation and human communities in prehistoric Greece. Saguntum 5, 91-103.

Out, W.A., Vermeeren, C., Hänninen, K., 2013. Branch age and diameter: useful criteria for recognising woodland management in the present and past? J. Archaeol. Sci. 40 (11), 4083-4097.

Paradis-Grenouillet, S., Dufraisse, A., 2018. Deciduous oak/chestnut: Differential shrinkage of wood during charcoalification? Preliminary experimental results and 
implications for wood diameter study in anthracology. Quaternary Int. 463, 258-267.

Pernaud, J.-M., 1997. Paléoenvironnements végétaux et sociétés à l'Holocène dans le nord du Bassin Parisien: anthracoanalyses de sites archéologiques d'Île-de-France et de Picardie: méthodologie et paléoécologie. Unpubl. Ph. D. Thesis, Université Paris IPanthéon-Sorbonne.

Picornell Gelabert, L., Asouti, E., Allué Martí, E., 2011. The ethnoarchaeology of firewood management in the Fang villages of Equatorial Guinea, central Africa: Implications for the interpretation of wood fuel remains from archaeological sites. J. Anthropol Archaeol. 30 (3), 375-384.

Ponomarenko, E., Ershova, E., Ponomarenko, D., Stashenkov, D., Kochkina, A., 2020 Tracing land use history using a combination of soil charcoal and soil pollen analyses: an example from colluvial deposits of the Middle Volga Region. J. Archaeol. Sci.: Rep. 31. https://doi.org/10.1016/j.jasrep.2020.102269.

Schweingruber, F.H., 2007. Wood Structure and Environment. Springer Science \& Business Media; Springer Verlag Berlin, Heidelberg.

Scott, A.C., Damblon, F., 2010. Charcoal: Taphonomy and significance in geology, botany and archaeology. Palaeogeogr. Palaeoclimatol. Palaeoecol. 291 (1-2), 1-10.

Slocum, D.H., Mac Ginnis, E.A., Beall, F.C., 1978. Charcoal yield, shrinkage, and density changes during carbonization of oak and hickory woods. Wood Sci. 11 (1), 42-47.

Taylor, M., Bamforth, M., Robson, H.K., Watson, C., Little, A., Pomstra, D., Milner, N., Carty, J.C., Colonese, A.C., Lucquin, A., Allen, S., 2018. The Wooden Artefacts. In: Milner, N., Conneller, C., Taylor, B. (Eds.), Star Carr Volume 2: Studies in Technology, Subsistence and Environment. White Rose University Press, York, pp. 367-418.

Terral, J.F., Mengüal, X., 1999. Reconstruction of Holocene climate in southern France and eastern Spain using quantitative anatomy of olive wood and archaeological charcoal. Palaeogeogr., Palaeoclimatol Palaeoecol. 153, 71-92.

Terral, J.F., 2000. Exploitation and management of the olive tree during prehistoric times in Mediterranean France and Spain. J. Archaeolog. Sci. 27 (2), 127-133.

Terral, J.-F., Durand, A., 2006. Bio-archaeological evidence of olive tree (Olea europaea L.) irrigation during the Middle Ages in Southern France and North Eastern Spain. J. Archaeol. Sci. 33 (5), 718-724.

Théry-Parisot, I., 2001. Économie des combustibles au Paléolithique: expérimentation, taphonomie, anthracologie. Dossier de Documentation Archéologique 20. CNRS Éditions, Paris.

Théry-Parisot, I., 2002. Gathering of firewood during the Palaeolithic. In: Thiébault, S. (Ed.), Charcoal analysis: methodological approaches, palaeoecological results and wood uses: proceedings of the Second International Meeting of Anthracology, Bar International Series 1063, Oxford Archaeopress, pp. 143-250.

Théry-Parisot, I., Costamagno, S., Henry, A. (Eds.) 2009. Fuel managment during the Palaeolithic and Mesolithic period. New tools, new interpretations. Proceedings of the xv World congress (Lisbon, 4-9 september 2006). BAR Series 1914 Oxford, Archaeopress.

Théry-Parisot, Isabelle, Chabal, Lucie, Chrzavzez, Julia, 2010. Anthracology and taphonomy, from wood gathering to charcoal analysis. A review of the taphonomic processes modifying charcoal assemblages, in archaeological contexts. Palaeogeogr. Palaeoclimatol. Palaeoecol. 291 (1-2), 142-153. https://doi.org/10.1016/j.palaeo. 2009.09.016.

Théry-Parisot, I., Henry, A., 2012. Seasoned or green? Radial cracks analysis as a method for identifying the use of green wood as fuel in archaeological charcoal. J. Archaeol. Sci. 39 (2), 381-388.
Théry-Parisot, I., Henry, A., Chrzavzez, J., 2016. Apport de l'expérimentation à la compréhension des pratiques sociétales en anthracologie: gestion et utilisation du bois de feu dans les sociétés préhistoriques. Cadernos do Lepaarq 25 (13), 485-509.

Théry-Parisot, I., Thiébault, S., Delannoy, J., Ferrier, C., Feruglio, V., Fritz, C., Geneste, J., 2018. Illuminating the cave, drawing in black: wood charcoal analysis at ChauvetPont d'Arc. Antiquity 92 (362), 320-333.

Thiébault, S. (Ed.) 2002. Charcoal analysis: methodological approaches, palaeoecological results and wood uses: proceedings of the Second International Meeting of Anthracology. Bar International Series 1063, Oxford Archaeopress.

Vernet, J.-L., ed., 1992. Les charbons de bois, les anciens écosystèmes et le rôle de l'homme. Bulletin de la Société Botanique de France, 139, 2-4, Société Botanique de France, Paris.

Vidal-Matutano, P., 2017. Firewood and hearths: Middle Palaeolithic woody taxa distribution from El Salt, stratigraphic unit Xb (Eastern Iberia). Quaternary Int. 457, 74-84.

Vidal-Matutano, P., Henry, A., Théry-Parisot, I., 2017. Dead wood gathering among Neanderthal groups: charcoal evidence from Abric del Pastor and El Salt (Eastern Iberia). J. Archaeol. Sci. 80, 109-121.

Vidal-Matutano, P., Hernández, C.M., Galván, B., Mallol, C., 2015. Neanderthal firewood management: evidence from stratigraphic unit IV of Abric Del Pastor (eastern Iberia). Quaternary Sc. Rev. 111, 81-93.

Vidal-Matutano, P., Alberto-Barroso, V., Marrero, E., García, J.C., Pou, S., Arnay de la Rosa, M., 2019. Vitrified wood charcoal and burnt bones from the pre-Hispanic site of Chasogo (Tenerife, Canary Islands, Spain). J. Archaeol. Sci.: Rep. 28. https://doi.org/ 10.1016/j.jasrep.2019.102005.

Vidal-Matutano, P., Blasco, R., Sañudo, P., Fernández Peris, J., 2019. The anthropogenic use of firewood during the European Middle Pleistocene: charcoal evidence from levels XIII and XI of Bolomor Cave, Eastern Iberia (230-160 ka). Environ. Archaeol. 24 (3), 269-284.

Zhilin, M., Savchenko, S., Hansen, S., Heussner, K., Terberger, T., 2018. Early art in the Urals: New research on the wooden sculpture from Shigir. Antiquity 92 (362), 334-350.

Paloma Vidal-Matutano $^{\mathrm{a}, \mathrm{b}, *}$, Auréade Henry ${ }^{\mathrm{b}}$, Yolanda Carrión-Marco ${ }^{\mathrm{c}}$, Ethel Alluéd,e

a TARHA Research Group, Universidad de Las Palmas de Gran Canaria, Pérez del Toro 1, 35004 Las Palmas de Gran Canaria, Spain

${ }^{\mathrm{b}}$ Université Côte d'Azur, CNRS-CEPAM, Nice, France

${ }^{\mathrm{c}}$ PREMEDOC Research Group, Universitat de València, Avda. Blaco Ibáñez, 28, 46010 Valencia, Spain

d IPHES, Institut Català de Paleoecologia Humana i Evolució Social, Zona Educacional 4 Campus Sescelades URV (Edifici W3), 43007 Tarragona,

Spain

e Àrea de Prehistòria, Universitat Rovira i Virgili (URV), Av. Catalunya 35, 43002 Tarragona, Spain

E-mail address: paloma.vidal@ulpgc.es (P. Vidal-Matutano).
* Corresponding author at: TARHA Research Group, Universidad de Las Palmas de Gran Canaria, Pérez del Toro 1, 35004 Las Palmas de Gran Canaria, Spain. 